\title{
Correction to: Definitive hematopoietic stem/progenitor cells from human embryonic stem cells through serum/ feeder-free organoid-induced differentiation
}

Selami Demirci ${ }^{1}$, Juan J. Haro-Mora ${ }^{1}$, Alexis Leonard ${ }^{1}$, Claire Drysdale ${ }^{1}$, Daniela Malide ${ }^{2}, K^{\prime}$ eyvan Keyvanfar ${ }^{3}$, Khaled Essawi ${ }^{1}$, Raul Vizcardo ${ }^{4}$, Naritaka Tamaoki ${ }^{4}$, Nicholas P. Restifo ${ }^{4}$, John F. Tisdale ${ }^{1 *}$ and Naoya Uchida ${ }^{1}$

Correction to: Stem Cell Res Ther (2020) 11:493 https://doi.org/10.1186/s13287-020-02019-5

The original article [1] contains an error in the captions of Additional Files 11 and 12.

In each caption, the word 'confocal' should be replaced by 'two-photon'.

\begin{abstract}
Author details
'Sickle Cell Branch, National Heart Lung and Blood Institute (NHLBI)/National Institute of Diabetes and Digestive and Kidney Diseases, National Institutes of Health (NIH), 9000 Rockville Pike, Bldg. 10, 9N112, Bethesda, MD 20892, USA. ${ }^{2}$ Light Microscopy Core Facility, NHLBI, NIH, Bethesda, MD, USA. ${ }^{3}$ Clinical Flow Core Facility, NHLBI, NIH, Bethesda, MD, USA. ${ }^{4}$ National Cancer Institute, Center for Cancer Research, NIH, Bethesda, MD, USA.
\end{abstract}

Published online: 17 December 2020

\section{Reference}

1. Demirci S, et al. Definitive hematopoietic stem/progenitor cells from human embryonic stem cells through serum/feeder-free organoid-induced differentiation. Stem Cell Res Ther. 2020;11:493 https://doi.org/10.1186/ s13287-020-02019-5.

\footnotetext{
The original article can be found online at https://doi.org/10.1186/s13287020-02019-5.

* Correspondence: johntis@mail.nih.gov

${ }^{1}$ Sickle Cell Branch, National Heart Lung and Blood Institute (NHLBI)/National Institute of Diabetes and Digestive and Kidney Diseases, National Institutes of Health (NIH), 9000 Rockville Pike, Bldg. 10, 9N112, Bethesda, MD 20892, USA

Full list of author information is available at the end of the article
}

C C The Author(s). 2020 Open Access This article is licensed under a Creative Commons Attribution 4.0 International License, which permits use, sharing, adaptation, distribution and reproduction in any medium or format, as long as you give appropriate credit to the original author(s) and the source, provide a link to the Creative Commons licence, and indicate if changes were made. The images or other third party material in this article are included in the article's Creative Commons licence, unless indicated otherwise in a credit line to the material. If material is not included in the article's Creative Commons licence and your intended use is not permitted by statutory regulation or exceeds the permitted use, you will need to obtain permission directly from the copyright holder. To view a copy of this licence, visit http://creativecommons.org/licenses/by/4.0/ The Creative Commons Public Domain Dedication waiver (http://creativecommons.org/publicdomain/zero/1.0/) applies to the data made available in this article, unless otherwise stated in a credit line to the data. 